\title{
НАУЧНО-ИСТРАЖУВАЧКА СТУДИЈА ОД ОБЛАСТА УСВОЈУВАҢЕ НЕМАЈЧИН ЈАЗИК
}

(Age Effectes in the Initial Stages of Second Language Acquisition of English, Ана Лазарова-Никовска, Скопје, 2018)

\section{A SECOND LANGUAGE ACQUISITION RESEARCH STUDY}

(Age Effectes in the Initial Stages of Second Language Acquisition of English, Ana Lazarova-Nikovska, Skopje, 2018)

Лилјана Митковска

Универзитет ФОН, Скопје

liljana.mitkovska@fon.edu.mk

Liljana Mitkovska

FON University, Skopje

liljana.mitkovska@fon.edu.mk

Монографијата Age Effects in the Initial Stages of Second Language Acquisition of English (Влијанието на возраста во почетните стадиуми на усвојување немајчин јазик) од Ана Лазарова-Никовска е оригинален и темелен научен труд кој обработува една значајна тема од областа изучување немајчин јазик, на којашто до сега не ѝ било посветено заслужено внимание во македонската наука за јазикот. Студијата се базира на систематски организирано и доследно спроведено истражување на усвојувањето на англиските негативни и прашални реченици од страна на македонски говорители на две возрасни нивоа: деца 8-10 години и возрасни 20-60 години. Резултатите од истражувањето даваат комплетен увид во почетните стадиуми на изучување на овие структури од јазикот цел (J2), како од аспект на механизмите на усвојување на новите структури така и во поглед на влијанието на мајчиниот јазик (J1) во тој процес. Притоа централно место зазема споредбата на 
процесите на усвојување кај децата и кај возрасните изучувачи, со што оваа студија се вклучува во теориските дискусии за 'критичниот период' во усвојувањето немајчин јазик, за возрасната граница и за учеството на универзалната граматика наспрема влијанието на J1 во процесот на усвојување на јазикот цел. Со тоа, оваа монографија придонесува за расветлување на повеќе клучни прашања во дисциплината усвојување немајчин јазик, што ѝ дава општотеориска важност. Таа е од посебно значење за македонската применета лингвистика, со оглед на фактот што вакви истражувања со македонски изучувачи се ретки.

Проблематиката обработена во оваа монографија е образложена во шест поглавја плус заклучен дел, по што следи и обемна библиографија од околу 400 наслови на извори од предметната литература кои се дискутираат во текстот. На крајот се приложени материјалите од експерименталното истражување и дескриптивната статистика. Текстот е целосно напишан на англиски јазик. Вредноста на оваа монографија е во воедначената застапеност на теориски и практичен (експериментален) дел, кои систематски се испреплетуваат и сочинуваат една интегрална целина.

Теориското образложение на проблематиката се состои од две целини. Во поглавјата 1-3 се разгледуваат прашања од областа изучување немајчин јазик кои се директно поврзани со предметот и со целите на спроведеното истражување. Прашањето за влијанието на возраста во изучувањето немајчин јазик и хипотезата за критичен период во усвојувањето јазик (Critical Period Hypothesis in Language Acquisition) се разгледуваат во првото поглавје од аспект на негенеративните приоди. И покрај комплексноста на проблемот и големиот обем на теоретски и истражувачки студии од областа, со бројни контрадикторни ставови, авторката успева да даде јасна слика за правците на истражување и отворените прашања. Оттука таа извлекува важни сознанија кои ги користи во планирањето на истражувањето и формирањето на истражувачките цели.

Второто поглавје е посветено на преглед на генеративните теории и истражувања за изучување немајчин јазик, каде што се вклучени и ставовите за критичниот период и влијанието на возраста од гледна точка на овој лингвистички правец. Ова поглавје има централна позиција во теорискиот преглед бидејќ истражувањето е базирано на генеративниот приод. Авторката забележува дека во однос на влијанието на возраста во усвојувањето J2 постојат различни ставови и дека недостасуваат студии во кои систематски се споредуваат различни возрасни групи, па според тоа нејзиното истражување има за цел да ја пополни оваа празнина. Друг поттик за оформување на истражувањето произлегува од предлозите од некои теоретичари за разликите во усвојувањето на синтаксата и морфологијата условени од факторот возраст. Во согласност со тоа, во методологијата се вклучени инструменти за собирање податоци за усвојувањето на двата типа структури. 
Во третото поглавје се разгледуваат различни ставови во врска со улогата на J1 во усвојувањето на друг јазик. И тука, покрај општиот преглед, важно место заземаат прашањата за односот меѓу возраста и меѓујазичното влијание, со посебен акцент на почетните стадиуми во изучување на јазикот цел. Со тоа се заокружува теориската основа за релацијата меѓу факторите чие влијание се испитува врз јазичниот развој. Четвртото поглавје содржи анализа на англиските структури чие усвојување се испитува и нивните македонски еквиваленти според генеративниот лингвистички приод. Со оглед на фактот дека англискиот јазик не дозволува авансирање на глаголот маркиран по време, а македонскиот дозволува, постојат параметрички разлики меѓу двата јазика во синтаксата на негативните и на прашалните реченици. Од друга страна, македонскиот јазик има богат систем на глаголски наставки, за разлика од англискиот. Авторката си поставува цел да испита како се преструктуираат параметрите од J1 во почетните стадиуми на изучување за да се воспостават вредностите од J2 и каква е разликата меѓу изучувачите на различни возрасти.

Во двете последни поглавја се изложени истражувањето и анализата на резултатите. Истражувањето е замислено како експеримент во кој 30 возрасни испитаници и 30 деца, сите апсолутни почетници, се изложени на настава по англиски јазик со посебен акцент на целните структури. Наставата со компатибилни материјали и методи, прилагодени на возраста, се одвива во текот на 4 недели, по 90 минути двапати неделно. Целта е да се испита какви разлики ќе се појават во зависност од возраста во услови на изедначеност на другите параметри. Со тоа истражувањето опфаќа неколку важни теми и се стреми да одговори на неколку клучни прашања кои сѐ уште не се расчистени во теоријата за усвојување немајчин јазик. За да се испитаат поставените хипотези, на крајот од обуката се спроведуваат два типа на тестови: тест за проценка на граматичноста на синтаксата на J2, и тест со пополнување за проверка на усвоеноста на морфолошките форми. Резултатите се систематски прикажани и се поткрепени со статистичка анализа. Дискусијата е сеопфатна и навлегува длабоко во испитуваната проблематика преку споредба на добиените резултати со постоечките теориски ставови и резултати од други истражувања. Со тоа се доаѓ до неколку релевантни заклучоци: (1) влијанието на J1 е подеднакво присутно во двете возрасни групи, но тоа не преовладува; (2) резултатите во усвојувањето на синтаксата се слични, но се јавуваат значајни разлики во морфологијата, каде што возрасните постигнуваат пониски резултати; (3) меѓу двете групи постои квалитативна разлика во процесот на усвојување, со тоа што возрасните се потпираат повеќе на неврзаните, а децата на врзаните морфеми; (4) динамиката на усвојување на почетните стадиуми не е изедначена кај возрасната група, туку се издвојуваат две подгрупи: изучувачи на возраст 20-40 и 40-60 години, при што првата предничи во усвојувањето на синтаксата и во споредба со децата.

Издавањето на монографијата Age Effects in the Initial Stages of Second Language Acquisition of English од Ана Лазарова-Никовска е од непроценлива 
важност за македонската лингвистичка сцена, посебно за сите оние постари и помлади истражувачи кои се ориентирани кон применетата лингвистика. Таа претставува збогатување и од теориски и од практичен, методолошкоистражувачки аспект. Со сеопфатноста и конзистентноста во приодот ќе служи како одличен пример за доброконципиран истражувачки труд со цврста поврзаност на теориските поставки и истражувачките постапки и анализи. Самиот експеримент претставува пример за целосно обмислено истражување во кое сите параметри се теориски засновани и строго контролирани, што дава можности за извлекување релевантни заклучоци. Постапката е јасно објаснета и транспарентно презентирана, а прилозите со целосниот план на наставата и тестовите даваат можност да се реплицира во исти или во други услови. Со тоа оваа монографија ќе даде поттик за понатамошни истражувања во усвојувањето немајчин јазик во Република Македонија. Покрај тоа, монографијата на Ана Лазарова-Никовска може да се споредува со студиите кои придонесуваат за решавање на дилемите и градење на ставовите во областа изучување немајчин јазик и со тоа има свој придонес во теориските развојни текови во оваа област.

Оваа книга е наменета пред сѐ за лингвисти и за студенти по лингвистика, но заради добро организираното и достапно прикажување на обемниот материјал може де се користи и од наставници по јазик, па и од поширок круг читатели кои покажуваат интерес за процесите и принципите на изучување немајчин јазик. 